\title{
Effect of dietary protein quality on energy metabolism in growing chickens
}

\author{
BY R. NIETO, C. PRIETO, I. FERNÁNDEZ-FÍGARES AND J. F. AGUILERA \\ Estación Experimental del Zaidín (CSIC), Animal Nutrition Department, Profesor Albareda, \\ 1. 18008 Granada, Spain
}

(Received 18 October 1994-Revised 16 December 1994 - Accepted 6 January 1995)

\begin{abstract}
A slaughter experiment was carried out to study the effect of dietary protein quality on maintenance energy requirements and energy costs for protein accretion and fat deposition in fast-growing broilertype male chickens. Three isonitrogenous $(200 \mathrm{~g}$ crude protein $/ \mathrm{kg} \mathrm{DM})$ and isoenergetic $(14 \mathrm{~kJ}$ metabolizable energy (ME)/g DM) semipurified diets based on soyabean meal unsupplemented (diet $S$ ) or supplemented with $20 \mathrm{~g}$ L-lysine/kg (diet SL) or $2 \mathrm{~g}$ DL-methionine/kg (diet SM), in order to promote a decrease or an increase in growth rate respectively, were selected and given at four feeding levels (ad lib. or restricted to 40,28 and $18 \mathrm{~g} \mathrm{DM} / \mathrm{d}$, on average) to 10-d-old fast-growing male broiler-type chicks for 2 weeks. Both the efficiency with which $M E$ was used to support growth $\left(k_{\mathrm{g}}\right)$ and the maintenance requirements $\left(\mathrm{ME}_{\mathrm{m}}\right)$ significantly decreased inversely to the biological value of the dietary protein $\left(k_{\mathrm{g}}=0.660,0.600\right.$ and $0.572 ; \mathrm{ME}_{\mathrm{m}}=597,522$ and $464 \mathrm{~kJ} / \mathrm{kg} \mathrm{W}^{0.75}$ per d, for diets $\mathrm{SL}, \mathrm{S}$ and $\mathrm{SM}$ respectively). The partial efficiencies of use of ME for protein accretion $\left(k_{\mathrm{p}}\right)$ or fat deposition $\left(k_{\mathrm{f}}\right)$ were also inversely related, the former increasing with the quality of the protein offered. An alternative procedure was used to try to overcome the statistical problems inherent in the partition of ME between fat and protein.
\end{abstract}

Protein quality: Energy costs: Maintenance requirements: Chickens

Protein deposition depends to a great extent on amino acid supply and therefore on the quantity and the quality (biological value, BV) of dietary protein. While much work has been published on the effect of the concentration of protein in the diet on the utilization of dietary energy, very little has been reported (Fuller et al. $1987 a, b$ ) on the extent to which the utilization of dietary energy, and specifically the relative costs of protein and fat deposition, are modified by dietary protein quality. In a previous study (Aguilera \& Prieto, $1987 a$ ) we showed that growing rats given several sources of dietary protein which differed widely in their BV presented marked differences in $\mathbf{N}$ retention and subsequently in level of production and relative rates of protein and fat deposition. In these experiments there were differences in the efficiency of utilization of metabolizable energy (ME) for growth, while no differences in energy requirements for maintenance $\left(\mathrm{ME}_{\mathrm{m}}\right)$ attributable to dietary protein quality could be detected. The experimental design adopted was, however, unable to provide information on the effect of dietary protein quality on the partial efficiencies of ME utilization for protein $\left(k_{\mathrm{p}}\right)$ or fat $\left(k_{\mathrm{p}}\right)$ deposition. These experiments also involved changes in energy and/or protein intake. In this respect it has been reported that the intakes of both protein and non-protein energy (Fuller et al. $1987 a-c$ ) are associated with changes in protein accretion. We have now studied the effect of changing the rate of protein accretion without alteration in energy or protein intake, through supplementation of a basal diet based on soyabean with the limiting amino acid (methionine) or with an excess 
of a non-limiting amino acid (lysine). Increases in $\mathrm{N}$ retention have been associated with higher rates of both protein synthesis and breakdown in the whole body (Reeds et al. 1980). This may have an associated energy penalty and affect differences in the energy costs of protein deposition as dietary quality varies. In this respect, we also showed (Nieto et al. 1994) that in muscle of growing chickens an amino acid imbalance affected growth by changing protein degradation rates, without effect on protein synthesis. Although extrapolation of these results to the whole-body situation may be misleading, the hypothesis is that changes in the rate of protein degradation, assuming a constant rate of protein synthesis, through alterations in the BV of dietary protein, may influence the energetic costs of protein deposition. The aim of the present study was to provide additional information as to whether or not dietary protein quality has an influence on the utilization of dietary energy in growing animals. Apart from other reasons (economic; quality and quantity of previous work on responses to amino acids), the broiler type chick was used mainly because genetic selection has yielded an animal with high rates of protein and weight gain, an ideal circumstance for the present investigation. Preliminary aspects of these studies have been reported elsewhere (Nieto et al. 1994).

\section{MATERIALS AND METHODS}

\section{Animals, diets and experimental design}

White Rock male broilers ( $1 \mathrm{~d}$ old) were raised in conventional electrically heated chick battery brooders in a fully lit, controlled-temperature room $\left(30^{\circ}\right)$ and given a commercial starter diet for $10 \mathrm{~d}$. Then they were divided into three groups, each of approximately forty birds, of similar body weight (mean live weight 136 (SE 1.6) g), and individually housed in metabolism cages with a wire floor. After an adaptation period of $5 \mathrm{~d}$ to the diet studied, for an experimental period of $9 \mathrm{~d}$ three isonitrogenous $(200 \mathrm{~g}$ crude protein $/ \mathrm{kg} \mathrm{DM})$ and isoenergetic (14 kJ ME/g DM) semipurified diets were offered, based on soyabean meal deficient in methionine, either unsupplemented (S), supplemented with $2 \mathrm{~g}$ DL-methionine/ $\mathrm{kg}(\mathrm{SM})$ or supplemented with $20 \mathrm{~g} \mathrm{~L}-\mathrm{lysine} / \mathrm{kg}$ (SL) (Table 1) at four feeding levels ( $\mathrm{ad}$ lib. or restricted to 40,28 and $18 \mathrm{~g} \mathrm{DM} / \mathrm{d}$, on average). The birds had continuous access to water and the cages were arranged randomly. The environmental temperature was decreased gradually from $30^{\circ}$ for 1 -d-old chickens to $22^{\circ}$ at 4 weeks of age. The birds were kept under a daily lighting schedule of $14 \mathrm{~h}$ light and $10 \mathrm{~h}$ dark. Feed intake, corrected for spillage, was recorded. A partial collection of excreta (25\% of the total) was made daily and stored at $-20^{\circ}$ before freeze drying. $\mathrm{Cr}_{2} \mathrm{O}_{3}(10 \mathrm{~g} / \mathrm{kg})$ was included in the diets as a $\mathrm{Cr}_{2} \mathrm{O}_{3}$-starch-water bread and used as a marker to estimate total energy losses in excreta. Care was taken to remove feathers from the droppings tray. On days 16 (initial groups, mean live weight 172 (SE 3.3) g) and 25 (final groups, mean live weight 340 (SE 9.4) g) of age a sample of birds was slaughtered for body composition determination; the content of the digestive tract was rapidly removed and the whole birds were minced and stored at $-20^{\circ}$ until analysis.

\section{Calculation of metabolizable energy, energy retention and partition}

The DM content of feed and excreta was determined by standard procedures (Association of Official Analytical Chemists, 1975) and total $\mathrm{N}$ by a Kjeldahl procedure using mineralization (Block Digestor Selecta S-509), distillation units (Büchi Laboratoriums Technik AG, Flawil, Switzerland) and titration units (Metrom AG, Herisau, Switzerland). Gross energy (GE) was measured in an adiabatic bomb calorimeter (Gallenkamp Autobomb CBA 305, Loughborough, Leics). Samples were freeze-dried in a polyethylene 
Table 1. Composition of the experimental diets $(\mathrm{g} / \mathrm{kg})$

\begin{tabular}{|c|c|c|c|}
\hline & \multicolumn{3}{|c|}{ Diet } \\
\hline & $\begin{array}{c}\mathrm{S} \\
\text { (control) }\end{array}$ & SL & SM \\
\hline \multicolumn{4}{|l|}{ Ingredients } \\
\hline Soyabean meal* & $402 \cdot 0$ & $360 \cdot 0$ & $402 \cdot 0$ \\
\hline Maize oil & $55 \cdot 1$ & 55.6 & $55 \cdot 1$ \\
\hline Mineral and vitamin premix & $111 \cdot 3$ & $111 \cdot 3$ & $111 \cdot 3$ \\
\hline L-Lysine & - & $20 \cdot 0$ & - \\
\hline DL-Methionine & - & - & $2 \cdot 0$ \\
\hline Maize starch $\dagger$ & $431 \cdot 6$ & 453.6 & $429 \cdot 6$ \\
\hline \multicolumn{4}{|l|}{ Chemical composition } \\
\hline Dry matter $(\mathrm{DM})(\mathrm{g} / \mathrm{kg})$ & 924 & 930 & 930 \\
\hline Crude protein $(\mathrm{N} \times 6.25 ; \mathrm{g} / \mathrm{kg} \mathrm{DM})$ & 203.8 & $201 \cdot 3$ & 202.6 \\
\hline Ether extract $\ddagger$ & $68 \cdot 6$ & 68.3 & $68 \cdot 6$ \\
\hline Crude fibre & $15 \cdot 3$ & 13.9 & $15 \cdot 3$ \\
\hline $\mathrm{N}$-free extractives $\ddagger$ & $554 \cdot 4$ & $562 \cdot 3$ & $554 \cdot 4$ \\
\hline Metabolizable energy (kJ/g DM) & 14.7 & 14.5 & 14.6 \\
\hline
\end{tabular}

* Chemical composition (g/kg DM): crude protein, $532 \cdot 6$; ether extract, $26 \cdot 2$; crude fibre, $38 \cdot 8$; total minerals, 71.6.

$\dagger$ Ether extract: $9 \cdot 4 \mathrm{~g} / \mathrm{kg}$ DM.

$\ddagger$ Calculated from the nutrient composition of ingredients $(\mathrm{g} / \mathrm{kg} \mathrm{DM})$.

sheet of known energy value and their GE values were obtained by difference. Apparent ME intake (MEI) was determined from the GE content of the feed minus faecal and urinary energy (EE). Apparent metabolizability (q) was calculated as the ratio MEI:GE. Total $\mathrm{N}$ and energy retained (RE) were determined by the slaughter technique. RE was partitioned as energy retained as protein (REP; $N$ retention $\times 6.25$ ) and energy retained as fat (REF; the remainder). The values of 23.8 and $38.7 \mathrm{~kJ} / \mathrm{g}$ were used for the energy contents of protein and fat respectively.

To adjust for the differences in body weight between birds the results were scaled per $\mathrm{kg}$ body weight $(\mathrm{W})^{0.75}$. Measurements of energy balance of broiler chickens given the experimental diets at the four feeding levels considered were used to relate ME intake to $\mathrm{RE}$, both expressed as $\mathrm{kJ} / \mathrm{kg} \mathrm{W}^{0.75}$ per $\mathrm{d}$, using the linear regression:

$$
\mathrm{RE} / \mathrm{kg} \mathrm{W}^{0.75}=a_{1}+b_{1} \times \mathrm{MEI} / \mathrm{kg} \mathrm{W}^{0.75} \text { per } \mathrm{d}+\mathrm{e}_{\mathrm{i}} \text {. }
$$

This equation predicts $\mathrm{ME}_{\mathrm{m}}$ as the intercept on the $x$ axis, and the regression coefficient $\left(b_{1}\right)$ provides an estimate of the efficiency of utilization of ME above maintenance; $a_{1}$ is RE when intake is zero; $e_{i}$ is a random residual with null mean and variance $\sigma^{2}$.

Multiple regression equations (Kielanowski, 1965) were used with MEI as dependent variable and REP and REF as independent variables. The model used was:

$$
\mathrm{MEI} / \mathrm{kg} \mathrm{W}^{0.75}=a_{2}+b_{2} \mathrm{REP} / \mathrm{kg} \mathrm{W}^{0.75}+c_{2} \mathrm{REF} / \mathrm{kg} \mathrm{W}^{0 \cdot 75}+\mathrm{e}_{\mathrm{i}},
$$

where $a_{2}$ is a regression intercept interpreted as the maintenance requirements; $b_{2}$ and $c_{2}$ represent the energy costs and their reciprocals, $1 / b_{2}\left(k_{\mathrm{p}}\right)$ and $1 / c_{2}\left(k_{\mathrm{p}}\right)$, represent estimates of partial efficiencies of ME utilization for protein and fat deposition respectively; and $e_{i}$ is a random residual.

To try to avoid the problems of co-linearity inherent in the multiple regression procedure, regressions on principal components were also used (Bernier et al. 1987). 


\section{Statistical analysis}

Results were evaluated by a factorial analysis involving the three diets at either all four or the three restricted levels of intake (to equalize feeding). The statistical significance of differences between means were assessed by Tukey's or Bonferroni's $t$ test for paired or non-paired groups respectively. The data were also treated using linear and multiple regression analyses when appropriate. Regression on principal components was also used.

\section{RESULTS}

Feed intake, growth performance and utilization of $\mathrm{N}$ are presented in Table 2. Factorial analysis 3 (diet) $\times 4$ (level of feeding) of the data showed that DM intake and $\mathrm{N}$ intake, both expressed per $\mathrm{kg} \mathrm{W}^{0.75}$ per $\mathrm{d}$, remained unchanged; however, daily body gain and $\mathrm{N}$ retained were significantly different $(P<0.05)$ between treatments, increasing as the quality of dietary protein improved (SL $<\mathrm{S}<\mathrm{SM}$ ). Similar trends were observed in the factorial analysis 3 (diet) $\times 3$ (levels of restricted intake) but significant differences $(P<0.05)$ appeared only between diets SL and SM.

Results of energy deposition are shown in Table 3. By previous experience and calculation it was expected that within each diet level (including ad lib.) the birds would have similar energy and $\mathrm{N}$ intakes but MEI for diet SM was found to be significantly $(P<0.05)$ higher $\left(1318 \mathrm{~kJ} / \mathrm{kg} \mathrm{W}^{0.75}\right.$ per d; Table 3$)$ than that for diets SL and $\mathrm{S}$, which did not differ from each other (1240 and $\left.1249 \mathrm{~kJ} / \mathrm{kg} \mathrm{W}^{0.75} \mathrm{per} \mathrm{d}\right)$. This was due to differences in the metabolizability of energy (q), which was significantly $(P<0.05)$ higher for diet SM $(0.801)$ than for diets SL $(0.782)$ and $S(0.785)$. Consequently, in order to avoid the confounding effects of differences in MEI between treatments, the factorial analysis 3 (diet) $\times 3$ (only restricted levels of feeding) was also made. Overall, total RE was significantly higher $(P<0.05)$ for diet SM $\left(424 \mathrm{~kJ} / \mathrm{kg} \mathrm{W}^{0.75}\right.$ per d) than for diets SL and S ( 390 and $383 \mathrm{~kJ} / \mathrm{kg} \mathrm{W}^{0.75}$ per d respectively). REP tended to increase with the BV of protein $(\mathrm{SL}<\mathrm{S}<\mathrm{SM})$ although the effect was only significant $(P<0.05)$ for $\mathrm{SM}$. No significant differences in heat production or REF between treatments were found.

Table 4 summarizes the solutions to equation (1). There was a trend for the efficiencies of utilization of ME for production $\left(k_{\mathrm{g}}\right)$ to be negatively affected by dietary protein quality $(\mathrm{SL}<\mathrm{S}<\mathrm{SM})$. In order to estimate the standard deviation of the intercept $\left(\mathrm{ME}_{\mathrm{m}}\right)$, MEI was also regressed $v$. RE and the range of ME estimates were non-overlapping at 645-715, $564-644$ and $483-561 \mathrm{~kJ}^{-} \mathrm{kg} \mathrm{W}^{0.75}$ per d for diets SL, $\mathrm{S}$ and SM respectively.

The solutions to equation (2) are shown in Table 5. Our results indicate that $k_{\mathrm{p}}$ values increase and $k_{\mathrm{f}}$ values decrease on increasing the $\mathrm{BV}$ of dietary protein. No significant differences between treatments were found for $\mathrm{ME}_{\mathrm{m}}$. Also, multiple regression equations of ME above maintenance $\left(\mathrm{ME}_{\mathrm{g}}\right.$, calculated as $\left.\mathrm{MEI}-\mathrm{ME}_{\mathrm{m}}\right) v$. REP and REF were made. The results obtained $\left(k_{p}: 0.402,0.438\right.$ and $0.538 ; k_{\mathrm{f}}: 1.28,0.885$ and 0.618 , for diets $\mathrm{SL}, \mathrm{S}$ and SM respectively) were similar to those presented in Table 5.

Regression $v$. principal components, a biased regression technique, was also applied to the experimental data. Estimates of $\mathrm{ME}_{\mathrm{m}}$ were 628,569 and $519 \mathrm{~kJ} / \mathrm{kg} \mathrm{W}^{0.75}$ per d, for diets SL, S and SM respectively. Partial efficiencies of protein $\left(k_{\mathrm{p}}\right)$ and fat $\left(k_{\mathrm{f}}\right)$ deposition were $0.500,0.513$ and 0.575 , and $0.971,0.813$ and 0.649 , for diets SL, S and SM respectively.

As an alternative procedure, the energy costs of growth were recalculated assuming a constant theoretical value for $k_{\mathrm{f}}(0 \cdot 8)$. Accordingly, in each case the MEI ascribed to fat deposition $\left(\mathrm{REF} / k_{\mathrm{f}}\right)$ was subtracted from the total MEI and the residual MEI (for maintenance and protein deposition, $\mathrm{ME}_{\mathrm{m}+\mathrm{p}}$ ) was regressed $v$. REP. The estimates of $k_{\mathrm{p}}$ obtained were $0.366,0.383$ and 0.426 for diets SL, S and SM respectively. There were no 
Table 2. Feed intake, daily weight gain and nitrogen balance in broilers given diets of different protein quality*

(Mean values for the factor diet of the factorial analysis $3 \times 4$ (or $3 \times 3$ in parentheses))

\begin{tabular}{|c|c|c|c|c|}
\hline & \multicolumn{3}{|c|}{ Diet } & \multirow[b]{2}{*}{ Pooled SE } \\
\hline & SL & $\mathbf{S}$ & SM & \\
\hline DM intake $\left(\mathrm{g} / \mathrm{kg} \mathrm{W}^{0.75}\right.$ per $\left.\mathrm{d}\right)$ & $\begin{array}{l}85 \cdot 7^{\mathrm{a}} \\
\left(82 \cdot 2^{\mathrm{a}}\right)\end{array}$ & $\begin{array}{c}86 \cdot 1^{2} \\
\left(81 \cdot 7^{\mathrm{a}}\right)\end{array}$ & $\begin{array}{c}88 \cdot 8^{a} \\
\left(81 \cdot 5^{a}\right)\end{array}$ & $\begin{array}{c}1.01 \\
(0.54)\end{array}$ \\
\hline Body-wt gain $(g / d)$ & $\begin{array}{c}15 \cdot 6^{\mathrm{a}} \\
\left(13 \cdot 8^{\mathrm{a}}\right)\end{array}$ & $\begin{array}{l}18 \cdot 7^{\mathrm{b}} \\
\left(16 \cdot 3^{\mathrm{b}}\right)\end{array}$ & $\begin{array}{c}21 \cdot 6^{c} \\
\left(16 \cdot 7^{b}\right)\end{array}$ & $\begin{array}{l}0.46 \\
(0.201)\end{array}$ \\
\hline NI (g/kg W' ${ }^{0 \cdot 75}$ per d) & $\begin{array}{c}2 \cdot 79^{\mathrm{a}} \\
\left(2 \cdot 70^{\mathrm{a}}\right)\end{array}$ & $\begin{array}{c}2 \cdot 81^{\mathrm{a}} \\
\left(2 \cdot 70^{\mathrm{a}}\right)\end{array}$ & $\begin{array}{c}2 \cdot 89^{\mathrm{a}} \\
\left(2 \cdot 71^{\mathrm{a}}\right)\end{array}$ & $\begin{array}{c}0.076 \\
(0.018)\end{array}$ \\
\hline $\mathrm{NR}\left(\mathrm{g} / \mathrm{kg} \mathrm{W} \mathrm{W}^{0.75}\right.$ per d) & $\begin{array}{l}1 \cdot 20^{\mathrm{a}} \\
\left(1 \cdot 12^{\mathrm{a}}\right)\end{array}$ & $\begin{array}{l}1 \cdot 32^{b} \\
\left(1 \cdot 19^{\mathrm{a}}\right)\end{array}$ & $\begin{array}{c}1 \cdot 60^{\mathrm{c}} \\
\left(1 \cdot 40^{\mathrm{b}}\right)\end{array}$ & $\begin{array}{c}0.027 \\
(0.026)\end{array}$ \\
\hline NR/NI (\%) & $\begin{array}{c}42 \cdot 3^{\mathrm{a}} \\
\left(40 \cdot 6^{\mathrm{a}}\right)\end{array}$ & $\begin{array}{c}45 \cdot 9^{b} \\
\left(43 \cdot 5^{a}\right)\end{array}$ & $\begin{array}{c}54 \cdot 0^{c} \\
\left(50 \cdot 6^{b}\right)\end{array}$ & $\begin{array}{l}0.86 \\
(1.01)\end{array}$ \\
\hline
\end{tabular}

NI, nitrogen intake; $N R$, nitrogen retention.

a, b, c Mean values within a row bearing unlike superscript letters were significantly different, $P<0.05$.

* For details of procedures, see Table 1 and pp. 164-166.

Table 3. Energy deposition in broilers given diets of different protein quality*

(Mean values, expressed as $\mathrm{kJ} / \mathrm{kg} \mathrm{W}^{0.75}$ per $\mathrm{d}$, for the factor diet of the factorial analyses $3 \times 4$ and $3 \times 3$ )

\begin{tabular}{|c|c|c|c|c|c|c|c|c|}
\hline \multirow[b]{2}{*}{ Diet ... } & \multicolumn{3}{|c|}{ All 4 intake levels } & \multirow[b]{2}{*}{ Pooled SE } & \multicolumn{3}{|c|}{3 restricted intake levels } & \multirow[b]{2}{*}{ Pooled SE } \\
\hline & SL & $\mathbf{S}$ & SM & & $\mathrm{SL}$ & $\mathbf{S}$ & SM & \\
\hline GEI & $1581^{\mathrm{a}}$ & $1582^{\mathrm{a}}$ & $1639^{a}$ & $18 \cdot 7$ & $1516^{\mathrm{a}}$ & $1497^{a}$ & $1498^{a}$ & $10 \cdot 1$ \\
\hline EE & $341^{\mathrm{a}}$ & $333^{a}$ & $321^{\mathrm{a}}$ & $7 \cdot 4$ & $332^{\mathrm{a}}$ & $319^{a b}$ & $299^{\mathrm{b}}$ & $7 \cdot 3$ \\
\hline MEI & $1240^{\mathrm{a}}$ & $1249^{a}$ & $1318^{b}$ & $14 \cdot 8$ & $1184^{\mathrm{a}}$ & $1178^{\mathrm{a}}$ & $1199^{\mathrm{a}}$ & $9 \cdot 8$ \\
\hline q & $0 \cdot 782^{a}$ & $0 \cdot 785^{a}$ & $0.801^{\mathrm{b}}$ & 0.036 & $0.778^{\mathrm{a}}$ & $0 \cdot 782^{\mathrm{ab}}$ & $0.797^{\mathrm{b}}$ & 0.0458 \\
\hline RE & $425^{\mathrm{a}}$ & $433^{\mathrm{a}}$ & $489^{b}$ & $12 \cdot 6$ & $389^{\mathrm{a}}$ & $383^{a}$ & $424^{b}$ & $8 \cdot 7$ \\
\hline $\mathrm{HP}$ & $814^{\mathrm{a}}$ & $815^{\mathrm{a}}$ & $829^{a}$ & $9 \cdot 3$ & $795^{\mathrm{a}}$ & $795^{\mathrm{a}}$ & $774^{a}$ & $9 \cdot 5$ \\
\hline REP & $180^{\mathrm{a}}$ & $199^{\mathrm{b}}$ & $241^{\mathrm{c}}$ & $5 \cdot 7$ & $167^{\mathrm{a}}$ & $178^{\mathrm{a}}$ & $208^{b}$ & $3 \cdot 8$ \\
\hline REF & $248^{a}$ & $234^{a}$ & $249^{\mathrm{a}}$ & $11 \cdot 3$ & $224^{\mathrm{a}}$ & $205^{a}$ & $216^{a}$ & $8 \cdot 7$ \\
\hline
\end{tabular}

GEI, gross energy intake; EE, faecal and urinary energy; MEI, metabolizable energy intake; q, metabolizability of energy; RE, energy retained; HP, heat production (MEI-RE); REP, energy retained as protein $(\mathrm{N} \times 6.25 \times 23.8)$; REF, energy retained as fat (RE-REP).

$\mathrm{a}, \mathrm{b}, \mathrm{c}$ Mean values within a row with different superscript letters were significantly different $(P<0-05)$.

* For details of diets and procedures, see Table 1 and pp. 164-166.

significant differences between treatments, but $k_{\mathrm{p}}$ tended to increase with the BV of protein $(\mathrm{SL}<\mathrm{S}<\mathrm{SM})$.

\section{DISCUSSION}

There is evidence suggesting that a severe amino acid imbalance has a primary effect on feed intake which, in turn, can affect growth rate and carcass composition (Solberg et al. 1971; Tasaki et al. 1976; Okumura \& Mori, 1979; Summers \& Leeson, 1985). Amino acid 
Table 4. The relationship between metabolizable energy intake ( $M E I, k J / k g W^{0.75}$ per $\left.d\right)$ and energy retained $\left(R E, \mathrm{~kJ} / \mathrm{kg} W^{0.75}\right.$ per $\left.d\right)$ in broilers fed on diets of different protein quality*

\begin{tabular}{|c|c|c|c|c|}
\hline Diet & Linear regression equations & $r$ & RSD & $n$ \\
\hline SL & $\begin{array}{c}\mathrm{RE}=-395+0660 \mathrm{MEI} \\
(\mathrm{SE} 48)(\mathrm{SE} 0.0375)\end{array}$ & 0.936 & $50 \cdot 7$ & 46 \\
\hline$S$ & $\begin{array}{c}\mathrm{RE}=-314+0.600 \mathrm{MEI} \\
(\mathrm{SE} 44)(\mathrm{SE} 0.0340)\end{array}$ & 0.944 & $52 \cdot 9$ & 40 \\
\hline SM & $\begin{array}{c}\mathrm{RE}=-266+0.572 \mathrm{MEI} \\
(\mathrm{SE} 36)(\mathrm{SE} 0.0267)\end{array}$ & 0.966 & $44 \cdot 6$ & 35 \\
\hline
\end{tabular}

RSD, residual standard deviation

* For details of diets, see Table 1.

Table 5. Multiple regression equations of metabolizable energy intake (MEI) v. energy retained as protein $(R E P)$ and fat $(R E F)$ in broilers fed on diets of different protein quality*

(All values are expressed as $\mathrm{kJ} / \mathrm{kg} \mathrm{W}^{0.75}$ per $\mathrm{d}$ )

\begin{tabular}{|c|c|c|c|c|c|c|}
\hline Diet & Multiple regression equations & $k_{\mathrm{p}} \dagger$ & $k_{\mathrm{f}} \dagger$ & $R^{2}$ & RSD & $n$ \\
\hline SL & 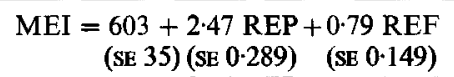 & 0.405 & 1.27 & 0.908 & $61 \cdot 2$ & 46 \\
\hline$S$ & 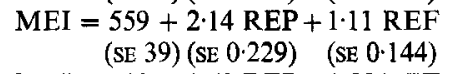 & 0.467 & 0.901 & 0.909 & $75 \cdot 4$ & 40 \\
\hline SM & $\begin{aligned} & \mathrm{MEI}= 519+1.73 \mathrm{REP}+1.55 \mathrm{REF} \\
&(\mathrm{SE} 40)(\mathrm{SE} 0.199) \\
&(\mathrm{SE} 0.175)\end{aligned}$ & 0.578 & 0.645 & 0.929 & $76 \cdot 1$ & 35 \\
\hline
\end{tabular}

RSD, residual standard deviation.

* For details of diets, see Table 1.

$\dagger$ Efficiency of energy utilization for protein $\left(k_{\mathrm{p}}\right)$ and fat $\left(k_{\mathrm{f}}\right)$ deposition.

excesses can also result in impaired growth performance (Snetsinger \& Scott, 1961; Griminger \& Fisher, 1968; Katz \& Baker, 1975; Han \& Baker, 1993). It is clear, therefore, that studies on amino acid supplementation require careful matching of intakes so that the effects of protein quality and quantity are not confounded.

In our experiment the control diet (S) was moderately deficient in methionine, and provided an adequate concentration of lysine. The supplementation with sufficient DLmethionine $(2 \mathrm{~g} / \mathrm{kg}$ diet $\mathrm{SM})$ or with an excess of L-lysine $(20 \mathrm{~g} / \mathrm{kg}$ diet SL) resulted in significant $(P<0.05)$ improvements or decreases respectively, in body gain, $\mathrm{N}$ retention and REP, while DM intake and $\mathrm{N}$ intake remained unchanged.

In nutritional studies the net efficiency of dietary ME utilization for growth $\left(k_{\mathrm{g}}\right)$ is closely related to the composition of body gain, i.e. to the ratio protein:fat retained. The deposition of fat is a more efficient process than that of protein, e.g. theoretical efficiencies with which the carbohydrates, lipids and proteins are employed in synthesis of body fat are $0.80,0.96$ and 0.66 respectively, and experimental values close to these have been observed. However, experimental values for protein deposition are usually much lower than theoretical due to the high cost of protein turnover (Blaxter, 1989). Indeed, published findings show that $k_{\mathrm{g}}$ decreases as protein: fat increases (Zausch et al. 1961; Zausch, 1969), 
an observation repeated in the current study (see also Table 6). The lower value found for diet SM may be related to the extra costs associated with protein deposition.

It is now well established (McCracken et al. 1980; Close et al. 1983) that at similar rates of energy intake protein accretion is higher and fat deposition lower as dietary protein concentration is increased to an optimum and also that at similar rates of protein intake, the lower the protein: energy relationship the greater the protein accretion (Close et al. 1983). Under such circumstances the greater the protein accretion the less total energy is retained, due again to the energy penalty associated with elevated protein turnover in response to changes in total protein supply.

With differences in protein quality rather than quantity the situation is less clear. In growing pigs offered a diet supplemented with lysine, the first limiting amino acid, Fuller et al. $(1987 a-c)$ found that the rate of heat production was not significantly changed, whereas the rate of protein accretion increased. The rate of fat deposition was inversely related to that of protein accretion. In these experiments the feed intake was not strictly controlled but improved daily gain and $\mathrm{N}$ retention $(P<0.05)$ were accompanied by increased total energy retention $(P<0 \cdot 05)$. Meanwhile supplementation with extra protein increased $\mathbf{N}$ retention but increased heat production. These changes in protein quality or quantity involved different metabolic responses. It was also found that increases in the rate of protein accretion resulting from lysine supplementation were brought about primarily by a reduction in body protein breakdown. This is believed to involve less energy than equivalent changes in protein synthesis (Lobley, 1988). Maruyama et al. (1978) also showed that in the chick an improvement in dietary protein quality had no effect on the rate of muscle protein synthesis despite increased gain, suggesting that the rate of protein degradation was reduced. Similar observations have been made for muscle from chickens receiving a similar improved diet quality to the current study (Nieto et al. 1994).

An alternative energy saving might involve less uric acid synthesis. In birds the excretion of excess amino acid $\mathbf{N}$ which is not used for protein synthesis takes place mainly as uric acid. The energy cost of this process is difficult to assess but the value of $1.4 \mathrm{MJ} \mathrm{ME} / \mathrm{mol}$ uric acid synthesized (Buttery \& Boorman, 1976) is usually preferred. Solberg et al. (1971) showed that in the chick a diet marginally deficient in methionine resulted in increased uric acid production. A similar observation was made by Thomas et al. (1969) for the laying hen given a lysine-deficient diet. Our results support this as the mean rates of $\mathrm{N}$ excretion were $1.59,1.49$ and $1.29 \mathrm{~g} / \mathrm{kg} \mathrm{W}^{\mathbf{0 . 7 5}}$ per d, for diets SL, S and SM respectively. The calculated extra costs would only account for +0.4 and $-0.4 \mathrm{~kJ}$ ME for diets SL and SM respectively, insufficient to account for the energy differences.

If, therefore, it is assumed that the increased protein accretion is achieved through a reduced protein degradation and that this does not incur extra heat production, then the question is raised whether the resultant improved energetic efficiency occurs in the 'maintenance' and/or 'growth' component. This is difficult to resolve because the regression approaches involved have strong co-linearity, i.e. values for $\mathrm{ME}_{\mathrm{m}}$ and $k_{\mathrm{g}}$ (or the partial efficiencies $k_{\mathrm{p}}$ and $k_{\mathrm{f}}$ ) are not independent and small changes in one component have an equal and opposite effect on the other. This means that such analyses must be treated with caution. Nevertheless, the current results indicate that improving diet quality may reduce both $\mathrm{ME}_{\mathrm{m}}$ and $k_{\mathrm{g}}$. This again would support the hypothesis of a reduced protein degradation which should have consequences above and below $\mathrm{N}$ equilibrium (protein balance).

In summary, the hypothesis of the present study was that a change in dietary protein quality, attained by adding either a limiting amino acid (DL-methionine) or a surplus of a non-limiting amino acid (L-lysine) to an otherwise adequate diet, would affect either the energy requirement for maintenance or the partition of $\mathrm{ME}$ for protein accretion or fat 


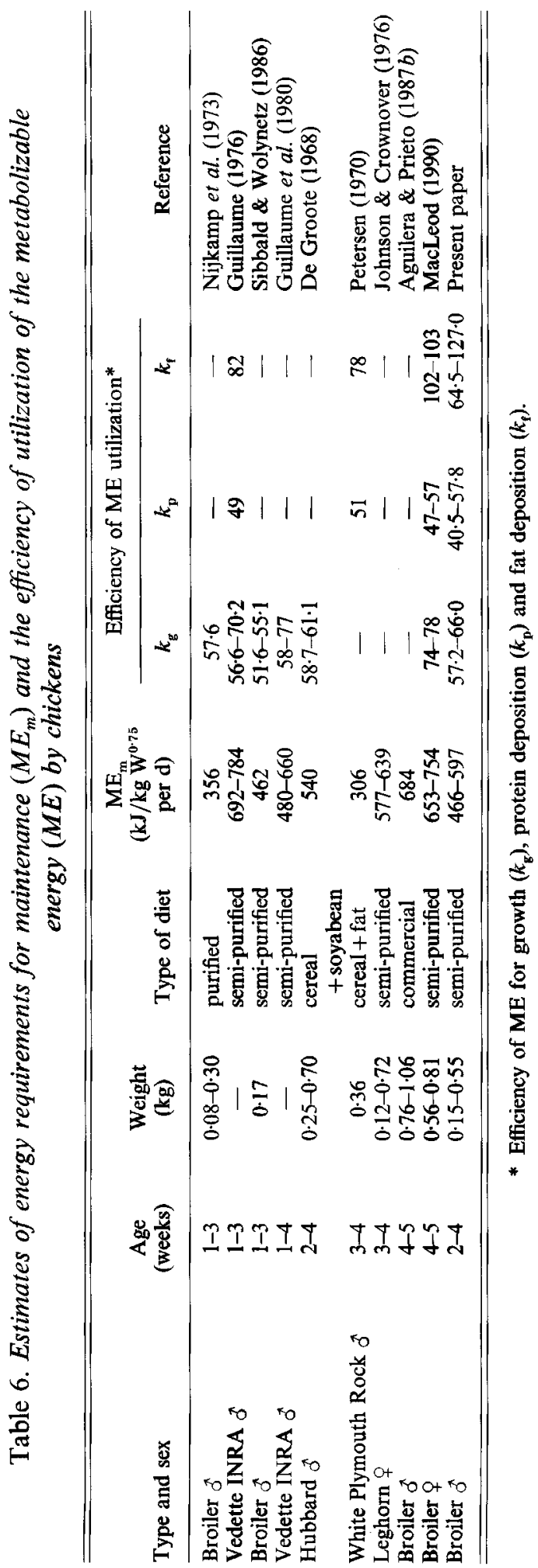


deposition. This hypothesis was substantiated by the present findings, as improvement in dietary protein quality affected not only the efficiency of $\mathrm{ME}$ utilization for growth $\left(k_{\mathrm{g}}\right)$ but also the $M E_{m}$ requirements and the partition of the same amount of retained energy between protein and fat.

The authors wish to thank Dr G. E. Lobley for helpful discussion and for critically reading the manuscript and Mrs E. Colmenero for skilful technical assistance. This work was supported by CICYT grant no. GAN91-0454.

\section{REFERENCES}

Aguilera, J. F. \& Prieto, C. (1987a). Effect of protein quality on energy requirements for maintenance in growing rats. Archives of Animal Nutrition, Berlin 10, 881-894.

Aguilera, J. F. \& Prieto, C. (1987b). Necesidades energéticas de mantenimiento en pollos en crecimiento (Energy requirements for maintenance in growing chickens). Archivos de Zootecnia 135, 165-172.

Association of Official Analytical Chemists (1975). Official Methods of Analysis, 12th ed. Washington, DC: AOAC.

Bernier, J. F., Calvert, C. C., Famula, T. R. \& Baldwin, R. L. (1987). Energetic efficiency of protein and fat deposition in mice with a major gene for rapid postweaning gain. Journal of Nutrition 117, 539-548.

Blaxter, K. L. (1989). Energy Metabolism in Animals and Man. Cambridge: Cambridge University Press.

Buttery, P. J. \& Boorman, K. N. (1976). The energetic efficiency of amino acid metabolism. In Protein Metabolism and Nutrition, pp. 197-512 [D. J. A. Cole, K. N. Boorman, P. J. Buttery, D. Lewis, R. J. Neal and H. Swan, editors]. London: Butterworths.

Close, W. H., Berschauer, F. \& Heavens, R. P. (1983). The influence of protein:energy value of the ratio and level of feed intake on the energy and nitrogen metabolism of the growing pig. British Journal of Nutrition 49, 255-269.

De Groote, G. (1968). Energetic evaluation of unstabilized and stabilized fish meals in terms of metabolizable energy and net energy for maintenance and growth. Feedstuffs, Minneapolis 40, 26.

Fuller, M. F., Cadenhead, A., Mollison, G. \& Seve, G. (1987a). Effects of amount and quality of dietary protein on nitrogen metabolism and heat production of growing pigs. British Journal of Nutrition 58, 277-285.

Fuller, M. F., Cadenhead, A., Reeds, P. J., Mollison, G. \& Seve, B. (1978 b). Effects of the amount and quality of dietary protein on amino acid, nitrogen and energy metabolism and their interrelationships in growing pigs. In Energy Metabolism of Farm Animals, European Association for Animal Production Publication no. 32, pp. 2-5 [P. W. Moe, H. F. Tyrrell and P. J. Reynolds, editors]. Totowa, New Jersey: Rowman and Littlefield.

Fuller, M. F., Reeds, P. J., Cadenhead, A., Seve, B. \& Preston, T. (1987c). Effects of the amount and quality of dietary protein on amino acid metabolism and protein turnover of pigs. British Journal of Nutrition 58, 287-300.

Griminger, P. \& Fisher, H. (1968). Methionine excess and chick growth. Poultry Science 47, 1271-1273.

Guillaume, J. (1976). Net utilization of the energy from carbohydrates and protein in the growing chick (1 to 3 weeks of age). In Energy Metabolism of Farm Animals, European Association for Animal Production Publication no. 19, pp. 281-284 [M. Vermorel, editor]. Clermont-Ferrand: G. de Bussac.

Guillaume, J., Scheele, C. W. \& Kussaibati, R. (1980). The effects of dietary protein, carbohydrate, fat and fibre on the net availability of metabolizable energy in the chick. In Energy Metabolism, European Association for Animal Production Publication no. 26, pp. 37-41 [L. E. Mount, editor]. London: Butterworths.

Han, Y. \& Baker, D. H. (1993). Effects of excess methionine or lysine for broilers fed a corn-soyabean meal diet. Poultry Science 72, 1070-1074.

Johnson, D. E. \& Crownover, J. C. (1976). Maintenance energy requirements of lean vs. obese growing chicks at equal age and body energy. In Energy Metabolism of Farm Animals, European Association for Animal Production Publication no. 19, pp. 121-124 [M. Vermorel, editor]. Clermont-Ferrand: G. de Bussac.

Katz, R. S. \& Baker, D. H. (1975). Methionine toxicity in the chick: nutritional and metabolic implications. Journal of Nutrition 105, 1168-1175.

Kielanowski, J. (1965). Estimates of the energy cost of protein deposition in growing animals. In Energy Metabolism, European Assaciation for Animal Production Publication no. 11, pp. 1320 [K. L. Blaxter, editor]. London: Academic Press.

Lobley, G. E. (1988). Protein turnover and energy metabolism in animals: interactions in leanness and obesity. In Leanness in Domestic Birds: Genetics, Metabolic and Hormonal Aspects, pp. 331-361 [B. Leclerq and C. C. Whitehead, editors]. INRA/Butterworths.

MacLeod, M. G. (1990). Energy and nitrogen intake, expenditure and retention at $20^{\circ}$ in growing fowl given diets with a wide range of energy and protein contents. British Journal of Nutrition 64, 625-637.

Maruyama, K., Sunde, M. L. \& Swick, R. S. (1978). Growth and muscle protein turnover in the chick. Biochemical Journal 176, 573-582.

McCracken, K. J., Eddie, S. M. \& Stevenson, W. G. (1980). Energy and protein nutrition of early-weaned pigs. 1. Effect of energy intake and energy:protein on growth, efficiency and nitrogen utilization of pigs between 8-32 d. British Journal of Nutrition 43, 289-304. 
Nieto, R., Palmer, R. M., Fernandez-Figares, I. Perez, L \& Prieto, C. (1994). Effect of dietary protein quality, feed restriction and short term fasting on protein synthesis and turnover in tissues of the growing chicken. British Journal of Nutrition 72, 499-507.

Nijkamp, H. J., van Es, A. J. H. \& Huisman, E. A. (1973). Retention of nitrogen, fat, ash, carbon and energy in growing chickens and in carp. In Energy Metabolism of Farm Animals, pp. 277-280 [K. H. Menke, H. J. Lantzch and J. R. Reichi, editors]. Universität Hohenheim Dokumentationsstelle.

Okumura, J. \& Mori, S. (1979). Effect of deficiencies of single essential amino acids on nitrogen and energy utilisation in chicks. British Poultry Science 20, 421-429.

Petersen, C. B. (1970). Efficiency of protein and fat deposition in growing chickens determined by respiration experiments. In Energy Metabolism of Farm Animals, European Association for Animal Production Publication no. 13, pp. 205-208 [A. Schürch and C. Wenk, editors]. Zurich: Juris Druck Verlag.

Reeds, P. J., Cadenhead, A., Fuller, M. F., Lobley, G. E. \& McDonald, J. D. (1980). Protein turnover in growing pigs. Effects of age and food intake. British Journal of Nutrition 43, 445-455.

Sibbald, I. R. \& Wolynetz, M. S. (1986). Effects of dietary lysine and feed intake on energy utilization and tissue synthesis by broiler chicks. Poultry Science 65, 98-105.

Snetsinger, D. C. \& Scott, H. M. (1961). Efficiency of glycine and arginine in alleviating the stress induced by dietary excesses of single amino acids. Poultry Science 40, 1675-1681.

Solberg, J., Buttery, P. J. \& Boorman, K. N. (1971). Effect of moderate methionine deficiency on food, protein and energy utilisation in the chick. British Poultry Science 12, 297-304.

Summers, J. D. \& Leeson, S. (1985). Broiler carcass composition as affected by amino acid supplementation. Canadian Journal of Animal Science 65, 717-723.

Tasaki, I., Sugahara, K. \& Okumura, J. (1976). Effect of amino acid deficiency on energy and protein utilization in growing chicks. In Energy Metabolism of Farm Animals, European Association for Animal Production Publication no. 19, pp. 101-104 [M. Vermorel, editor]. Clermont-Ferrand: G. de Bussac.

Thomas, O. A., Davidson, J. \& Boyne, A. W. (1969). Dietary factors affecting the utilisation of protein by laying hens and their effects on the concentration of certain nitrogenous constituents in the excreta. British Poultry Science 10, 67-82.

Zausch, M. (1969). Experiments on the total metabolism of growing cockerels by means of the simultaneous difference trial. In Energy Metabolism of Farm Animals, European Association for Animal Production Publication no. 12, pp. 401-406 [K. L. Blaxter, J. Kielanowski and G. Thorbek, editors]. Newcastle upon Tyne: Oriel Press.

Zausch, M., Bein, L. \& Gebhardt, G. (1961). Die Futterverwertung in Abhängigkeit vom Ernährungsniveau nach Untersuchungen an wachsenden Albinoratten (Feed evaluation in relation to different nutritional levels in experiments with growing Albino rats). In Symposium on Energy Metabolism, European Association for Animal Production Publication no. 10, pp. 94-104 [E. Brouwer and A. J. H. van Es, editors]. Rome: EAAP. 